\title{
Analisis Bauran Pemasaran Jasa Klinik Rawat Jalan pada RSUD di Propinsi Riau
}

\author{
BAMBANG SUROTO \\ Fakultas Ekonomi Universitas Lancang Kuning Pekanbaru \\ Jalan Yos Sudarso KM 8 Rumbai \\ Telp. (0761) 52581
}

\begin{abstract}
Marketing of hospital services is a challenge in the face of existing problems. At the hospital in Riau Province which is the government health facilities provide services which have the concept of the marketing mix 5 P namely: product, price, place, public relations, and positioning. Hospital marketing mix Riau province in line with the conditions mendepankan some key indicators include: product and services that can be offered outpatient services in hospitals and also services to the home or through an intermediary. Then the price is applied based on a predetermined price and cooperate with BPJS in financing and also with local government programs. Besides the problem location is placed in accordance with public demand for health services and coupled with clinics and health centers that serve the public or before reaching the hospital. Information is provided through socialization and implemented on an ongoing basis through various events and the placement of the existing priority health services in the province of Riau.
\end{abstract}

Keywords: Marketing Mix Hospital Services

Pemasaran adalah suatu proses sosial dan manajerial sehingga individu dan kelompok mendapatkan apa yang mereka butuhkan dan inginkan melalui penciptaan dan pertukaran produk dan nilai dengan yang lain (Kotler \& Keller, 2012 : 6). The American Marketing Association (Hollenson, 2003:9; Czinkota dan Kotabe, 2001:3) merumuskan definisi pemasaran yang lebih menekankan pada proses manajerial yaitu proses perencanaan dan penetapan konsepsi, penetapan harga, promosi dan distribusi gagasan, barang dan jasa untuk menciptakan pertukaran yang memuaskan tujuan individu dan organisasi. Definisi lain adalah sebagai berikut: Pemasaran adalah fungsi organisasi dan serangkaian proses untuk menciptakan, mengkomunikasikan dan menyampaikan nilai kepada pelanggan dan mengelola hubungan pelanggan sedemikian rupa sehingga menguntungkan organisasi dan stakeholdernya. (Groonros,2006:4)

Sejumlah filosofi atau orientasi organsiasi dapat dipilih dan digunakan dalam mencapai tujuan pemasaran. Filosofi atau orientasi organsiasi yang dipilih dijadikan pedoman seluruh kegiatan pemasaran. Kotler
\& Keller (2009:12-17) mengemukakan enam orientasi dalam kegiatan pemasaran, yaitu: konsep produksi, konsep produk, konsep penjualan, konsep pemasaran, konsep pelanggan dan konsep sosial dan kemasyarakatan. Sedangkan Hollensen (2003:9-14) mengelompokkan ke dalam dua filosofi atau orientasi perusahaan, yaitu the transactional marketing concept dan the relationship marketing consept. Pilihan atas satu atau beberapa filosofi atau orientasi didasarkan pada kondisi yang ada dan menjadi syarat berlakunya filosofi atau orientasi perusahaan itu.

Perkembangan sektor industri jasa, termasuk di dalamnya jasa kesehatan, tidak terlepas dari tuntutan masyarakat untuk tetap mendapatkan pelayanan kesehatan yang berkualitas. Berbagai upaya telah dilakukan guna meningkatkan pembangunan kesehatan yang lebih baik dan berdaya guna serta efisien, sehingga dapat menjangkau semua lapisan masyarakat. Untuk itu diperlukan upaya-upaya meningkatkan kualitas sumber daya, membenahi peralatan dan obat-obatan serta memperbaiki penampilan Rumah Sakit. 
Berdasarkan Undang-Undang Republik Indonesia Nomor 44 Tahun 2009 Tentang Rumah Sakit mempunyai tugas memberikan pelayanan kesehatan perorangan secara paripurna, pasal 5 untuk menjalankan tugas sebagaimana dimaksud dalam Pasal 4, Rumah Sakit mempunyai fungsi (a) penyelenggaraan pelayanan pengobatan dan pemulihan kesehatan sesuai dengan standar pelayanan rumah sakit; (b) pemeliharaan dan peningkatan kesehatan perorangan melalui pelayanan kesehatan yang paripurna tingkat kedua dan ketiga sesuai kebutuhan medis; (c) penyelenggaraan pendidikan dan pelatihan sumber daya manusia dalam rangka peningkatan kemampuan dalam pemberian pelayanan kesehatan; (d) penyelenggaraan penelitian dan pengembangan serta penapisan teknologi bidang kesehatan dalam rangka peningkatan pelayanan kesehatan dengan memperhatikan etika ilmu pengetahuan bidang kesehatan.

Sebuah tantangan yang sangat besar bagi pengelola rumah sakit saat ini,seperti yang di informasikan dalam Kompas,adalah jumlah warga Indonesia yang berobat ke luar negeri terus bertambah. Keunggulan teknologi, kemampuan medik, dan keramahan layanan masih menjadi alasan pendorongnya. Setiap tahun, triliunan rupiah devisa negara mengalir ke negara-negara tetangga. Menurut Hasbullah Thabrany pemerintah tidak dapat rumah sakitmenyalahkan rakyat yang ingin berobat ke luar negeri. Di Indonesia, pasien belum dianggap sebagai mitra rumah sakit, melainkan masih sebatas objek rumah sakit. Meski sejumlah rumah sakit pemerintah dan swasta gencar mengembangkan layanan kelas VIP (very important person) dan super-VIP, menurut Hasbullah, persepsi pasien Indonesia atas buruknya layanan rumah sakit tidak berubah. Modernisasi hanya terjadi pada penyediaan ruang dan peralatan medik, tetapi profesionalitas dan kemampuan tenaga medik serta pendukungnya belum tertata baik.

Permasalahan bauran pemasaran jasa pada perusahaan tentunya tidak jauh berbeda dengan bauran pemasaran jasa rumah sakit. Dalam penelitian ini akan memfokuskan kepada bauran pemasaran jasa rumah sakit yang mengintegrasikan beberapa konsep bauran pemasaran. Dalam pemasaran jasa, usaha mempengaruhi dan menarik minat konsumen dilakukan dengan mengunakan konsep yang dikenal dengan bauran pemasaran, yang terdiri dari product, price, promotion dan place. Oleh pemasar, bauran pemasaran itu dikelola dan dikendalikan secara terpadu untuk menghasilkan tanggapan yang diinginkan dari konsumen.

Dharmmesta dan Handoko (2000:26) menyatakan bahwa kegiatan inti dari sistem pemasaran, yaitu produk, harga, kegiatan promosi dan sistem distribusi, proses, orang, dan bukti physik.Bauran pemasaran jasa merupakan variabel-variabel terkendali yang dapat digunakan perusahaan untuk mempengaruhi tanggapan konsumen dari segmen pasar tertentu yang dituju perusahaan.Sebagaimana pemasaran industri yang memiliki bauran pemasaran tradisional, maka pada pemasaran jasa juga mengembangkan bauran pemasaran, pemasaran tradisional, service marketing, sampai dengan holistic marketing. Dimulai dari bauran pemasaran yang terdiri dari product, planning, pricing, branding, channelsof distribution, personal selling, advertising, promotion, packaging, display, servicing, physical handling, serta fact finding and analysis.

Lebih lanjut bahwa adanya perkembangan berkaitan dengan bauran pemasaran, pada tahun 1968 Mc Carthy dalam Tjiptono, 2009:8) mengembangkan bauran pemasaran tradisional yang terdiri dari product planning, pricing, branding, channels of distribution, personal selling, advertising, promotion, packaging, display, servicing, physical handling, Fact finding and analysis menjadi product price, place, promotion, and distribution. Lalu pada tahun 1981 Booms and Bitner mengembangkan bauran pemasaran Mc Carthy (1968) menjadi service marketing mix pada $4 \mathrm{P}$ ditambah dengan $3 \mathrm{P}$ yang terdiri dari product, price, place, promotion, participant, process, physical evidence. 
Bauran pemasaran selanjutnya dikembangkan lagi oleh Kotler (2009) menjadi $4 \mathrm{P}$ tradisional ditambah dengan $2 P$ yang terdiri dari product, price, place, promotion, political power, public opinion formulation. Lalu oleh Rapp dan Collins di tahun yang sama 1987 mengembangkan bauran pemasaran Kotler menjadi 4P tradisional dengan 2D yang terdiri dari dari product, price, place, promotion, data base dan dialogue. Dilanjutkan lagi oleh Brunner (1989) mengubah serta mengembangkannya menjadi 4C yang terdiri concept mix, cost mix, convenance mix dan communication mix.

Berdasarkan perkembangan bauran pemasaran di atas, maka bauran pemasaran jasa rumah sakit dalam penelitian ini adalah $5 \mathrm{P}$ yaitu produk, price, place, public relation, dan positioning yang diadaptasi dari Hoyle (2006:15) dari masing-masing marketing tools secara singkat akan dibahas di bawah ini meliputi : produk, price, place, public relation, dan positioning.

\section{METODE}

Penelitian ini menggunakan metode kualitatif, melalui wawancara kepada pasien rawat jalan dan pihak RSUD Propinsi Riau berkaitan dengan masalah bauran pemasaran jasa. Analisis data menggunakan analisis deskriptif.

\section{HASIL}

Berdasarkan hasil penelitian mengenai bauran pemasaran jasa rumah sakit di Propinsi Riau dapat diuraikan pada hasil berikut ini:

\section{Produk Jasa Rumah Sakit}

Menurut Kotler (2009:428) bahwa pemasaran jasa segala sesuatu yang dapat ditawarkan produsen untuk diperhatikan, diminati, dicari, digunakan, dikonsumsi pasar sebagai pemenuhan kebutuhan atau keinginan pasar yang bersangkutan. Produk juga adalah konsep secara keseluruhan atas obyek atau proses yang memberikan berbagai nilai bagi para pasien, karena barang dan jasa merupakan subkategori yang menjelaskan dua jenis produk. Istilah produk seringkali dipakai dalam pengertian yang luas untuk mengartikan barang atau produk manufaktur atau jasa.

Produk jasa merupakan suatu kinerja penampilan, tidak berwujud dan cepat hilang, lebih dapat dirasakan daripada dimiliki. Pada dasarnya bahwa konsumen tidak membeli barang atau jasa, tetapi membeli manfaat dan nilai dari sesuatu yang ditawarkan. Apa yang ditawarkan menunjukkan sejumlah manfaat yang bisa pelanggan dapatkan dari pembeli suatu barang atau jasa, sedangkan sesuatu yang ditawarkan itu sendiri dapat dibagi menjadi empat kategori, yaitu : barang nyata, barang nyata yang disertai dengan pelayanan, jasa utama yang disertai dengan barang dan pelayanan tambahan, dan jasa murni.

Menurut Kotabe dan Czinkota (2001:228), bahwa penawaran akan suatu produk/jasa dapat dibedakan berdasarkan tingkatan, yaitu : the core product, yaitu inti dari produk atau jasa itu sendiri, the tangible product (tampilan produk), diindikasikan dengan elemen-elemen pelayanan, seperti rancangan, warna, kemasan dan beberapa dimensi layanan fisik yang memberikan manfaat pada pelanggan, the augmented product (produk tambahan) seperti jaminan dan manfaat pelayanan, reputasi perusahaan, dan manfaat psikologi dari pelanggan.

Pada pelayanan jasa rumah sakit RSUD Propinsi Riau dapat dijelaskan bahwa menggambarkan uraian mengenai inti dari produk jasa itu sendiri dalam hal ini adalah intinya memberikan pelayanan rawat jalan, pasien akan datang berobat tetapi tidak dirawat di rumah sakit dan akan kontrol atau datang kembali ke rumah sakit. Kondisi ini dinilai bahwa pelayanan yang diberikan memang kondisinya demikian, hasil wawancara dengan informan berbicara menganai pelayanan yang diberikan untuk rawat jalan waktunya terbatas. Kemudian masalah elemen pelayanan yang diberikan memang tidak beragam dan hanya diberikan kepada pasien, memang terkadang pasien selain datang ke RSUD juga dokter mendatangi pasien di rumah tempat tinggal 
mereka. Kemudian juga berkaitan dengan produk ini dikemas dalam bentuk pelayanan publik gratis kepada masyarakat yang membutuhkan kecuali beberapa aspek tindakan. Layanan khusus diberikan dan juga memberikan pelayanan obat paten dan obat generik, sehingga pasien dengan mudan sesuai dengan selera dan kemampuan mendapatkan pelayanan rawat jalan.

\section{Harga Jasa}

Harga merupakan bauran pemasaran yang menghasilkan pendapatan, sedangkan unsur yang lainnya akan menimbulkan biaya. Harga juga merupakan satu bauran pemasaran yang paling fleksibel, dimana harga dapat berubah dengan cepat. Penentuan harga merupakan titik kritis dalam bauran pemasaran jasa karena harga menentukan pendapatan dari suatu pelayanan. Keputusan penentuan harga sangat signifikan di dalam penentuan nilai/manfaat yang diberikan kepada pelanggan dan memainkan peranan penting dalam gambaran kualitas dari pelayanan.

Dari sudut pandang pasien rawat jalan, harga merupakan prioritas kedua setelah nilai manfaat dari suatu produk. Harga adalah jumlah uang yang harus dibayar oleh pasien untuk hadir pada saat suatu event. Untuk menetapkan harga sebuah produk, rumah sakit umumnya memperhitungkan baik faktor eksternal maupun internal perusahaan. Situasi pasar, keadaan persaingan yang dihadapi, kondisi sosial ekonomi dan daya beli masyarakat pada umumnya adalah beberapa diantara faktor eksternal yang dapat mempengaruhi penetapan harga suatu produk oleh perusahaan itu sendiri. Dibandingkan dengan industri lain, faktor internal atau falsafah keuangan event itu lebih dominan bagi penyelenggara untuk menetapkan harga event.

Setiap event diselenggarakan untuk tujuan yang berbeda-beda dengan falsafah keuangan yang berbeda pula. Event konvensi yang diadakan oleh sebuah organisasi, misalnya, tidak diselenggarakan untuk mendatangkan keuntungan secara langsung, tetapi lebih merupakan sebuah biaya pelayanan guna meningkatkan kinerja anggotanya. Untuk itu diperlukan strategi penentuan harga dalam menggunakan dua penentuan yaitu: tarif premium pada permintaan sedang naik dan tarif diskon pada saat permintaan sedang menurun.

Namun harga jasa pada RSUD propinsi Riau khususnya untuk rawat jalan dilayani secara asuransi, pembiayaan terkadang ada yang gratis diberikan kepada pasien, namun ada juga yang berbayar. Jasa pelayanan ini tergantung juga bentuk permintaan daripada pasien yang membutuhkan pelayanan. Kelas pelayanan diberikan, dengan kelas pelayanan ini diharapkan kepada pasien yang memiliki atau mampu membayar dengan biaya asuransi yang lebih tinggi akan mendapatkan pelayanan yang berkualitas lebih baik dibandingkan dengan pasien yang mampu membayar lebih rendah.

\section{Tempat/lokasi pelayanan}

Keputusan mengenai lokasi pelayanan yang akan digunakan melibatkan pertimbangan bagaimana penyampaian jasa kepada pelanggan yang berlangsung. Tempat juga penting sebagai lingkungan dimana dan bagaimana jasa akan diserahkan, sebagai bagian dari nilai dan manfaat dari jasa. Keanekaragaman jasa membuat penyeragaman strategi tempat menjadi sulit. Masalah ini melibatkan pertimbangan bagaimana interaksi antara organisasi penyedia jasa dan pelanggan. Pandangan Bennet, Anthony R, (2000:10), bahwa lokasi pelayanan yang akan digunakan dalam memasok jasa kepada pelanggan yang dituju sebagai dasar dari kunci keberhasilan.

Beberapa masalah yang berhubungan dengan lokasi dan saluran perlu dipertimbangkan ketika mencari pendekatan penyampaian jasa yang tepat. Lokasi berhubungan dengan keputusan yang dibuat oleh perusahaan mengenai di mana operasi dan stafnya akan ditempatkan. Yang paling penting dari lokasi adalah tipe dan tingkat interaksi yang terlibat. Ada tiga macam tipe 
interaksi antara penyedia jasa dan konsumen yaitu, (1) pelanggan mendatangi penyedia jasa, (2) penyedia jasa mendatangi pelanggan, (3) penyedia jasa dan pelanggan melakukan interaksi melalui perantara.

Penting tidaknya sebuah lokasi akan sangat tergantung pada jenis jasa yang ditawarkan. Beberapa kunci yang harus dipertimbangkan oleh seorang manajer jasa. (1) apa yang diperlukan pasar? Bila jasa tidak tersedia di suatu lokasi yang nyaman pembelian jasa akan terhambat atau tertunda dan akan menyebabkan konsumen apakah merubah pikiran atau merubah pilihan, (2) kecenderungan apa yang ada didalam sektor aktivitas jasa dimana organisasi jasa beroperasi, apakah persaingan dapat memasuki pasar, (3) sejauh mana kefleksibelan jasa? Apakah jasa itu berorientasi teknologi atau orang dan sejauh mana kefleksibelannya terpengaruh oleh lokasi? (4) apakah organisasi mempunyai kewajiban untuk menempatkan jasa di suatu lokasi yang nyaman? (5) apakah sistem prosedur dan teknologi baru dapat dipakai untuk mengatasi kelemahan keputusan lokasi yang lama, (6) sejauh mana kepentingan jasa pelengkap terhadap keputusan lokasi, (7) apakah lokasi organisasi sejenis mempengaruhi keputusan lokasi. Pertanyaanpertanyaan di atas dapat digunakan oleh pemasaran jasa untuk membuat keputusan mengenai lokasi.

Apabila dilihat dari hasil wawancara dengan informan berkaitan dengan masalah lokasi RSUD yang tersebar, pada hakekatnya lokasi pelayanan RSUD mudah dijangkau, namun jalur tempuh untuk mendapatkan pelayanan perlu melewati jalur klinik atau puskesmas sebagai perantara ke rumah sakit, jika pasien tidak mampu ditangani oleh klinik atau puskesmas baru pasien akan dirujuk ke RSUD. Hal ini menghindari menumpuknya pasien di RSUD dan mengoptimalkan pelayanan yang diberikan oleh klinik atau puskesmas. Namun dari sisi masyarakat pelayanan seperti ini memberikan dampak kepada waktu yang digunakan dan dialami oleh pasien untuk mendapatkan pelayanan lebih cepat.

\section{Public Relation / Publisitas}

Ada sebuah perbedaan khusus antara public relation/publisitas dan iklan. Melalui iklan, kita mengatakan sesuatu tentang event. Sebaliknya, melalui persepsi yang dibangun public relation, orang lain yang mengatakan sesuatu tentang event tersebut. Opini atau penilaian yang disampaikan oleh pihak ketiga itu akan menghasilkan perhatian masyarakat terhadap event.

Public relation salah satu unsur utama dari konsep 5P dalam pemasaran event. Melalui kegiatan public relation pemasar dapat mengarahkan pikiran dan persepsi khalayak secara keseluruhan tentang event sehingga memberikan kredibilitas lebih terhadap iklan. Tugas pemasar disektor event adalah mengarahkan, membimbing, dan membujuk pasien sasaran dengan berbagai taktik dan cara guna membangkitkan minat pasien untuk mendapatkan pelayanan rawat jalan.

Berdasarkan hasil wawancara yang dilakukan dengan pihak rumah sakit, dijelaskan bahwa sosialsiasi yang dilakukan dalam rangka publisitas, karena pelayanan rumah sakit merupakan program pemerintah, perlu program ini disampaikan kepada masyarakat yang menjadi sasaran dalam pelayanan. Keberhasilan sosialisasi ini akan berdampak kepada pemahaman dari pasien untuk dengan mudah memanfaatkan jasa pelayanan kesehatan yang disediakan.

\section{Positioning / Penempatan}

Positioning/penempatan adalah kunci bagi keberhasilan pemasaran produk jasa kesehatan (Hoyle, 2006:23).Positioning/penempatan adalah segala usaha yang dilakukan pengusaha untuk menempatkan produknya pada posisi yang prima dalam benak (persepsi) pasien agar bisa bersaing dengan produk jasa rumah sakit lain dalam memenuhi kebutuhan pasien akan rumah sakit. Kotler dan Amstrong (2001:20) mengartikan posisi produk sebagai 
tempat yang diduduki produk dalam benak pasien dibandingkan dengan produk jasa lainnya atau pesaing. Positioning/penempatan itu diartikan oleh pasien berdasarkan beberapa atribut penting dari produk tersebut dalam memenuhi kebutuhannya.

Agar dapat memenangkan persaingan dalam pemasaran, pemasar dituntut : (1) mengetahui apa yang menjadi kebutuhan pasien, (2) memilih keunggulan manfaat dan perbedaan yang dimiliki produknya dibandingkan produk pesaing, dan (3) menentukan bagaimana mengembangkan strategi pemasaran melalui bauran pemasaran (bauran 5P) guna menampakkan keunikan dan perbedaan itu dalam benak pasien.

Upaya itu dilakukan melalui evaluasi beberapa faktor. Dalam hal ini penyelenggara event, menurut Hoyle (2006:42-50) menyarankan beberapa pertanyaan adalah sebagai berikut: Siapa yang diharapkan hadir dan berpartisipasi pada event ini; apa kebutuhan mereka? Mana yang akan dipenuhi oleh event ini?; event apa yang dilaksanakan oleh para pesaing; berapa harga yang ditawarkan kepada pasien dan berapa investasi yang diperlukan untuk hadir peserta oleh para pesaing dibandingkan dengan event yang akan diselenggarakan; apa keunikan dan perbedaan event ini dibandingkan dengan event pesaing dan bagaimana mengoptimalkannya; bagaimana tanggapan pasar terhadap konsep event yang akan diselenggarakan; dengan menjawab pertanyaan-pertanyaan diatas dan melalui strategi positioning yang melibatkan seluruh marketing mix (5P) yang dibangun demi kesuksesan event tersebut.

Dari hasil wawancara mengenai pelayanan jasa rumah sakit yang disediakan RSUD di Propinsi Riau dapat dijelaskan bahwa di daerah ini setiap daerah memiliki RSUD dan setiap RSUD memiliki pasilitas puskesmas dan atau juga klinik kesehatan yang bekerjasama dengan BPJS. Kondisi ini memberikan posisi sendiri bagi organisasi dalam rangka mengoptimalkan pelayanannya kepada pasien khususnya rawat jalan.

\section{PEMBAHASAN}

Berkaitan dengan kondisi tersebut, maka dapat dijelaskan bauran pemasaran jasa RSUD Propinsi Riau sejalan dengan kondisi yang mendepankan beberapa indikator kunci antara lain: produk jasa yang ditawarkan bisa berupa jasa rawat jalan di rumah sakit dan juga pelayanan ke rumah dan atau melalui perantara. Kemudian mengenai harga yang diterapkan berdasarkan harga yang telah ditetapkan dan bekerjasama dengan BPJS dalam pembiayaannya dan juga dengan program pemerintah daerah. Selain itu masalah lokasi diletakkan sesuai dengan kebutuhan masyarakat terhadap jasa kesehatan dan ditambah dengan klinik dan atau puskesmas yang melayani masyarakat sebelum sampai ke RSUD. Informasi diberikan melalui sosialisasi dan dilaksanakan secara berkesinambungan melalui berbagai event dan penempatan yang ada menjadi prioritas pelayanan jasa kesehatan di Propinsi Riau.

Hasil penelitian ini memberikan makna bahwa dalam memasarkan produk jasa kesehatan perlu bersikap mengejar pasien, karena hal ini berkaitan dengan hak pelayanan kesehatan merupakan haknya warga masyarakat dan janji pemerintah. Sehingga dalam pelaksanaannya perlu lebih aktif dalam memberikan berbagai dukungan. Penelitian ini mendukung pendapat yang disampaikan oleh Hoyle (2006:15) dari masing-masing marketing tools secara singkat akan dibahas di bawah ini meliputi : produk, price, place, public relation, dan positioning.

\section{SIMPULAN}

Pemasaran jasa rumah sakit menjadi tantangan tersendiri dalam menghadapi persoalan yang ada. Pada RSUD Propinsi Riau yang merupakan fasilitas kesehatan pemerintah menyediakan jasa pelayanan yang memiliki konsep bauran pemasaran $5 \mathrm{P}$ yakni: produk, price, place, public relation, dan positioning. Bauran pemasaran jasa RSUD Propinsi Riau sejalan dengan kondisi yang mendepankan beberapa indikator kunci 
antara lain: produk jasa yang ditawarkan bisa berupa jasa rawat jalan di rumah sakit dan juga pelayanan ke rumah dan atau melalui perantara. Kemudian mengenai harga yang diterapkan berdasarkan harga yang telah ditetapkan dan bekerjasama dengan BPJS dalam pembiayaannya dan juga dengan program pemerintah daerah. Selain itu masalah lokasi diletakkan sesuai dengan kebutuhan masyarakat terhadap jasa kesehatan dan ditambah dengan klinik dan atau puskesmas yang melayani masyarakat sebelum sampai ke RSUD. Informasi diberikan melalui sosialisasi dan dilaksanakan secara berkesinambungan melalui berbagai event dan penempatan yang ada menjadi prioritas pelayanan jasa kesehatan di Propinsi Riau.

\section{DAFTAR RUJUKAN}

Bennet, Anthony R, 2000, The Big Book Of Marketing : Lessons And The Best. Practices

Czinkota dan Kotabe, 2001, Marketing Management,. South-western College
Dharmmesta dan Handoko, 2000, Manajemen Pemasaran Prespektif Perilaku Konsumen. FE UGM Yogyakarta

Groonros, 2006, "The Perceived Service Quality Concept-A Mistake?', Journal Managing Service Quality, Vol. 11 No. 3, pp. 150-52

Hollenson, 2003, Marketing management : A Reationship Approach

Hoyle, 2006, Event Marketing. Jakarta: PPM. Hardjana

Kotler \& Keller, 2009, Marketing Management, Edisi Terjemahan 13 th Edition, Pearson International Edition.

Kotler dan Amstrong, 2001, Marketing Management, The Millenium Edition. Prentice Hal. New Jersey

Tjiptono, 2009, Pemasaran Jasa. Cetakan Ketiga. Bayumedia Publishing : Malang

Undang-Undang Republik Indonesia Nomor 44 Tahun 2009 Tentang Rumah Sakit 